\title{
The assessment of Indonesian EFL students' reading comprehension ability using Reading Evaluation and Decoding System (READS)
}

\author{
Indah Fajar Wahyuni \\ Universiti Sains Malaysia, 11800 Gelugor, Penang, Malaysia \\ wahyuladiqi@gmail.com
}

ARTICLE INFO

Article history

Received 15 December 2019

Revised 24 March 2020

Accepted 16 August 2020

Available Online 15 January 2021

Keywords

assessment

reading comprehension

Barrett's taxonomy

\begin{abstract}
This study focused on reading comprehension ability of the English Department students in answering READS, MCQ questions. READS is an alternative standardized assessment system that is capable of measuring reading comprehension ability. This is a descriptive study based on Barrett's Taxonomy levels, such as literal comprehension, reorganization, and inferential comprehension. This study consisted of 122 students of the English Department academic year 2015 through 2018 at one of the private universities in Yogyakarta, Indonesia. This study analysis utilized the three Barrett's taxonomy scales to identify whether the students were at meet the standard, below standard, above standard or at academic warning. Finding of the research indicated that $27.8 \%$ students categorized into academic warning (Band 2 and 3), 46.7\% students categorized into below standard (Band 4) and 25.5\% students categorized into meet standard (Band 5). Consequently, READS as an alternative assessment will guide the teachers to design specific reading material based on students' needs.
\end{abstract}

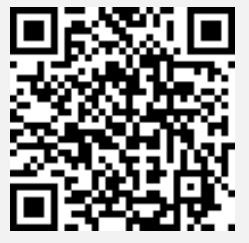

This is an open access article under the CC-BY-SA license.

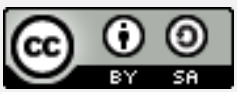

\section{Introduction}

Currently, the assessment used by university-level only evaluates the performance of students based on the score. Sometimes teachers cannot decide the students' ability when two students get the same rating in tests because most teachers prepare evaluation without considering the standardized tests. Since there are no specific tests on reading at private or state universities, the researcher is eager to establish such a reading assessment test to measure students' reading ability accurately. As an essential language skill, reading is also required in academic and social life. Furthermore, Oakley (2011) stated that reading comprehension could be defined as the skill of combining background knowledge with reading texts. This statement indicates that students should have a specific skill to combine between reading and comprehension. Then, they can understand the reading texts easily.

Moreover, based on the Asia-Pacific region (OECD, 2017), Indonesia was far behind its neighborhood countries. To improve students' quality, the Indonesian government implemented the EFL in the classroom with English lessons included as a compulsory subject for junior and senior high school students. There are two purposes of primary and secondary schools in learning English. First, students need to be prepared to read English texts to go to university.

Since reading is one of their most important goals, the researcher uses adapted READS as a reading assessment for private university students in Indonesia. The original READS (Reading 
Evaluation and Decoding System) is a standardized reading assessment developed in Malaysia (Mohamed, Eng, \& Ismail, 2010). Then, it is adapted into Indonesia READS based on the Indonesian curriculum and syllabus.

\subsection{The Concept of Test, Evaluation, and Assessment}

Brown (2004: 3) stated that "A test is a method of measuring a person's ability, knowledge, or performance in a given domain". A test consists of specific questions, but several test components should be prepared before designing a test. Brown (2004: 3) mentioned three parts of the test. First, it is an instrument - a set of techniques, procedures, or items - the requires performance on the part of the test taker. Second, a test must measure. Some tests measure general ability, while others focus on particular competencies or objectives.

On the other hand, assessment and evaluation describe collecting and interpreting evidence for some purposes. In language learning there are two crucial implications of language assessment; first, it is the assessment object (the thing being assessed) and second, the medium of the evaluation (the means through and within which to consider) (Johnston \& Turner., 2003).

The essential purpose of any assessment is to collect information to decide on some categories. Stanley and Tognolini (2011) defined an assessment as involving professional judgement based upon an image formed by collecting student performance data. There are several ways for teachers to collect data from student assessment. These have been summarised by Stanley and Tognolini (2011: 26) along a continuum of assessment methods (Figure 1) that range from 'less formal or unstructured methods' to 'more formal or highly structured methods' of collecting information.

\begin{tabular}{|c|c|c|c|}
\hline $\begin{array}{l}\text { Less } \\
\text { Formal }\end{array}$ & & & $\begin{array}{l}\text { More } \\
\text { Formal }\end{array}$ \\
\hline $\begin{array}{l}\text { Unstructured } \\
\text { - chance meetings } \\
\text { - conversations }\end{array}$ & $\begin{array}{l}\text { Slightly structured } \\
\text { - questionnaires } \\
\text { - observation } \\
\text { - student self-assessment }\end{array}$ & $\begin{array}{l}\text { More structured } \\
\text { - classroom tests } \\
\text { - checklists } \\
\text { - practical work } \\
\text { - project work } \\
\text { - case studies }\end{array}$ & $\begin{array}{l}\text { Most structured } \\
\text { " examinations } \\
\text { - standardised tests } \\
\text { - published aptitude tests }\end{array}$ \\
\hline
\end{tabular}

Fig. 1. Methods for Collecting Information on Student Performance

Based on Figure 1, in this study, the adapted READS (Reading Evaluation and Decoding System) is referred to as a standardized test of reading assessment developed in Malaysia (Mohamed, Eng, \& Ismail, 2010). There are three components on READS. After the test is completed, students can get the result directly. READS was developed based on Barrett's Taxonomy as cited in Alderson (1984). READS contains three components of reading comprehension skills such as literal, reorganization and inferential. The skill level on READS is categorized from easy to difficult level. For example, literal involves recognition and recall of ideas and information. Then, reorganization is dealing with the organizing of ideas and information. Last, inferential is ideas and information used as the basis for making intelligent hypotheses. All skills categories are significant, especially to measure the reading ability of students.

\subsection{Reading and Reading Comprehension}

There are several definitions of reading. It is not only related to the ability to understand the explicit meaning of the passage presented. The reader also has to understand the explicit and implicit meaning of the text. Besides, Pumfrey (1977: 2) stated:

It is, in essence, a constructive thinking process which includes comprehension of explicit and implicit meaning. It involves the application, analysis, evaluation and imagination.

Furthermore, Harmer (2001: 199) stated, when the learners read a story or a newspaper, they deploy a range of respective skills. It means that reading is the individual skill that requires the readers' ability to create interaction between the world's linguistic knowledge and knowledge. 
Reading can be concluded as an active process to get meaning from printed words or verbal symbols in written text from the definition above. To get the intended purpose of the text, the reader must understand what she or he is reading. During this process, the reader combines her or his language skills and the background of world knowledge to understand the meaning.

Reading is an essential skill for students to get knowledge from books. By reading, students can easily contribute to the information in their neighborhood. Snow (2001: 9) defined reading comprehension as the process of simultaneously extracting and constructing meaning through interaction and involvement with written language.

To enhance the ability of students, Indonesia government support the EFL in class with English lessons provided as a compulsory subject for junior and high school students. Moreover, based on the need for a more targeted and effective education system in Indonesia, the writer adjusts a specific assessment which refers to Barrett's Taxonomy. It starts from the syllabus under Barrett's Taxonomy of reading comprehension. The description of the program and Barrett's Taxonomy is stated as the following:

Table 1. Sub-skills of Reading

\begin{tabular}{|c|c|c|}
\hline $\begin{array}{l}\text { Skill categories in Barrett's } \\
\text { Taxonomy }\end{array}$ & $\begin{array}{l}\text { Skill specifications in the Indonesian } \\
\text { English Language Syllabus/textbook }\end{array}$ & $\begin{array}{c}\text { Barrett's Taxonomy of } \\
\text { Reading Comprehension }\end{array}$ \\
\hline Literal comprehension & $\begin{array}{l}\text { i. scanning of simple text (functional text) } \\
\text { ii. identify the topic sentence in simple text }\end{array}$ & $\begin{aligned} \text { i. } & \text { recognition of detail } \\
\text { ii. } & \text { recognition of the main idea } \\
\text { iii. } & \text { recognition of sequence } \\
\text { iv. } & \text { recognition of comparison } \\
\text { v. } & \text { cause and effect }\end{aligned}$ \\
\hline Reorganization & $\begin{array}{l}\text { i. identify the text of intermediate level } \\
\text { ii. identify descriptive text and cause and } \\
\text { effect }\end{array}$ & $\begin{aligned} \text { i. } & \text { classifying } \\
\text { ii. } & \text { outlining } \\
\text { iii. } & \text { summarizing } \\
\text { iv. } & \text { Synthesizing }\end{aligned}$ \\
\hline Inferential & $\begin{array}{l}\text { identify various genres of texts, including } \\
\text { inferring reading }\end{array}$ & $\begin{aligned} \text { i. } & \text { inferring supporting details } \\
\text { ii. } & \text { understanding main ideas } \\
\text { iii. } & \text { inferring sequence } \\
\text { iv. } & \text { inferring comparisons } \\
\text { v. } & \text { inferring cause and effect } \\
& \text { relationship }\end{aligned}$ \\
\hline
\end{tabular}

\section{Research Method}

Airasian, Mills, and Gay stated (2012: 130): "The first step in sampling is to define the population to which results generalizable." The population may be any size and may cover almost any geographical area. Furthermore, Airasian (2012) defined:

A distinction is made between the population to which the researcher would ideally like to generalize study results, the target population, and the community. The researcher can realistically select subjects known as the accessible population.

In this study, the sample consists of 122 students of the English Education Department at one of the private universities in Yogyakarta, Indonesia. The samples were collected randomly from students year 2015 through 2018.

This study refers to a descriptive study based on the three levels of Barrett's Taxonomy, namely literal comprehension, reorganization, and inferential comprehension. The instrument which was used in this study is called adapted READS (Reading Evaluation and Decoding System). The researcher chooses READS as the main instrument since it is standardized of reading assessment to determine student reading comprehension proficiency in Malaysia since 2014. READS was developed based on Barrett's Taxonomy as cited in Alderson (1984). 


\subsection{Content Validity of Adapted READS}

According to Gay and Airasian (2003), validity is the appropriateness of the interpretations made from tests score. There are also three kinds of validity; content validity, criterion-related validity, and construct validity. In this study, the researcher used content validity which was verified by six experts. All of the experts have experience in the English assessment. Four of the experts are from Universitas Ahmad Dahlan and two experts are from State University of Yogyakarta. They were asked to verify the adapted READS based on the statements below:

1) The online system is suitable in the Indonesia setting.

2) There are no cultural biases such as currency, names, place, etc. All of the texts which refers to the Malaysian context already changed into Indonesian context.

3) The format of the test is clear.

a) The type of texts is suitable.

b) The length of the passage is proper.

4) The level of difficulty is appropriate for university level.

Before READS was tested to Indonesian students, the researcher asked several experts to evaluate the READS texts. Most of the original READS passage consists of Malaysian cultures, such as currency, addressing names, name of places and specific events. Several terms like Puan, Tuan and Cik are not familiar for Indonesian. The researcher then has to adapt all of the Malaysian cultural text into Indonesian cultural passage to avoid cultural bias. Finally, Indonesia READS given to students was changed based on the experts' opinions and suggestions.

\section{Findings and Discussion}

There are several steps in establishing a reading assessment. First, the researcher has to check the curriculum and syllabus of English, especially reading skills, because the curriculum is the primary source for developing the encoder and matrix. This process is related to the prescribed standard. READS is the evaluation standard system to provide respiratory, encoder, matrix and decoder. The test result is the performance standard that gives the complete information "What" students should know and be able to do at each grade level and band.

READS contains three components of reading comprehension skills such as literal, reorganization and inferential. The skill levels on READS are categorized from easy to difficult level. For examples, literal involves recognition and recall of ideas and information. Then, reorganization is dealing with the organizing of ideas and information. Last, inferential is ideas and information used as the basis for making intelligent hypotheses. All skills categories are significant, especially to measure the reading ability of students.

Finally, all students were assessed using READS and Barrett's Taxonomy scale to determine the sublevels of questions stated in Table 1. After students completed the test, the researcher used the test results to categorize the students into Performance Bands (Band 1 to Band 5) as shown in Table 2. There were several steps to establish Indonesian cut scores. First, the $\mathrm{Z}$ score was utilized to calculate the cut scores based on the formula on the $\mathrm{z}$ score. Then, the cut scores for the performance bands were developed based on $\mathrm{z}$-score. Negative z-score indicates that the students scored below the mean, whereas positive zscore indicates that the students score is above the mean.

Table 2. Range of Score for the Performance Bands

\begin{tabular}{cccccc}
\hline Bands & Band 1 & Band 2 & Band 3 & Band 4 & Band 5 \\
Scores & $0-15$ & $16-22$ & $23-29$ & $30-41$ & $42-60$ \\
Performance Standard & Academic & Academic & Academic & Below & Meet \\
& Warning & Warning & Warning & Standard & Standard \\
\hline
\end{tabular}

Based on the finding of the Z-scores, the value of mean and standard deviation was calculated. The mean was 29.0, and the standard deviation was 7.0. The raw score then rounded to the nearest 
whole number. The scores for the various performance bands were then calculated based on z-score, as shown in Table 2. After classifying the performance bands' cut scores, then identify the learners' specific reading abilities by referring to the Reading Matrix.

Finally, the performance bands for each educational level are showed in Table 3. The reading performance of the students categorized into:

1) 31 students $(25.5 \%)$ categorized into meet standard (Band 5)

2) 57 students $(46.7 \%)$ categorized into below standard (Band 4)

3) 28 students $(22.9 \%$ ) categorized into academic warning (Band 3 )

4) 6 students $(4.9 \%)$ categorized into academic warning (Band 2)

Table 3. Performance Bands for Each Educational Level

\begin{tabular}{cccccc}
\hline LEVEL & Band 1 & Band 2 & Band 3 & Band 4 & Band 5 \\
\hline Year 1 & - & 2 & 12 & 22 & 16 \\
Year 2 & - & 2 & 9 & 16 & 10 \\
Year 3 & - & 1 & 4 & 3 & 3 \\
Year 4 & - & 1 & 3 & 57 & 31 \\
TOTAL & & 6 & 28 & 31 \\
\hline
\end{tabular}

Table 3 clarifies the level of performance standards. For example, Year 4 students who get Band 5 would be categorized as "meet standard". If students Year 4 get Band 3, they would be categorized into "below standard" and students Year 3 who get Band 5 would be categorized into "above standard." The performance band results indicate that the English Department's reading ability is low because some students get Band 2 and Band 3. Only a few students who get Band 5.

The finding showing that $46.7 \%$ of the students are below standard could be due to various factors. Juyandegan as cited in Rosalina \& Nasrullah (2019), stated that the factors include cognitive, affective, and psychomotor processes. To optimize learning, equal attention should be given to the three sides. The cognitive process occurs when students try to understand the text, main idea, etc. The affective one is the student emotional factors, such as self-esteem, inhibition, and anxiety when they try to comprehension the text. Then, the psychomotor factor takes place when considering the eye movements in any reading and mouth movements in reading aloud activity.

In addition, in relation to affective factors, especially for reading English academic texts, Hasyim (2018) puts an emphasis on the significance of self-efficacy. It is the students' interest to read. The higher self-efficacy perceived by a student, that he or she is capable of doing, the stronger student's interest to read English academic text.

However, according to Performance Band, it was interesting to note that several students in year one (1) and year two (2) categorized into "above standard". Although they are still in Year one, they get Band 5. Those finding indicated that several students could do the test precisely. On the other hand, students in Band 2 can understand only a few words that they read. These students have difficulty answering literal comprehension questions, which is the easiest level of comprehension questions. Also, they cannot answer reorganisation comprehension questions. In fact, as university students, they are required to run a constructive thinking process dealing with comprehending explicit and implicit meanings, the process demanding the application, analysis, evaluation and imagination (Pumfrey, 1977).

Thus, the teachers have to focus on teaching reading skills to help students make an inference and draw a conclusion. It is important that they design the reading class as with supporting academic atmosphere through their variety of reading tasks, and texts as needed by the students.

Such diagnostic information is beneficial for a teacher to give an appropriate material in their learning process. By using READS, teachers can benchmark students' reading abilities precisely. READS can be used as formative and summative. READS's management system can assess, grade, and generate sophisticated data useful in decision-making by an educational professional. 


\section{Conclusion}

Preparing standardized reading comprehension assessment for a student is very important to determine the level of reading ability. Teachers should prepare several steps to develop a standardized assessment. The adapted READS could be one of the best choices to design in the English Department. The result of the adapted READS test will give a specific indicator of student reading ability. It will describe what students can do and cannot do. Finally, EFL teacher can design suitable materials for students based on their reading ability.

\section{References}

Airasian, P.W, Mills, G. \& Gay, L.R. (2012). Educational research: Compentencies for analysis and application. USA: Pearson Education, Inc.

Alderson J. C. \&, Urquhart, A.H. (1984). Reading in a foreign language (Applied linguistics and language study). London: Longman Pub Group.

Brown, H. D. (2004). Language assessment: Principles and classroom practices. White Plains, NY: Pearson Education, Inc.

Gay, L., \& Airasian, P. (2003). Educational research competencies for analysis and application (7th ed.). Upper Saddle River, NJ Pearson International Edition.

Harmer, J. (2001). The practise of English language teaching third edition. New York: Pearson Education.

Hasyim, F. (2018). The effects of self-efficacy on motivation of reading English academic text . Ahmad Dahlan Journal of English Studies, 5(1), 25-34. http://dx.doi.org/10.26555/adjes.v5i1.8597

Johnson, B., \& Turner, L. A. (2003). Data collection strategies in mixed methods research. In A. Tashakkori \& C. Teddlie (Eds.), Handbook of mixed methods in social and behavioural research (1st ed.), 297- 319). Thousand Oaks, CA: Sage.

Mohamed, A. R., Eng, L. S., \& Ismail, S. A. M. M. (2010). Making Sense of reading scores with Reading Evaluation and Decoding System (READS). English Language Teaching, 3(3), 35-46.

Oakley, G (2011). The assessment of reading comprehension cognitive strategies: Practices and perceptions of Western Australian teachers. Australian Journal of Language and Literacy, 34, 279-292

OECD (2017). Economic outlook for Southeast Asia, China and India 2017: Addressing energy challenges. Paris: OECD Publishing. http://dx.doi.org/10.1787/saeo-2017-en

Pumfrey, P. D. (1977). Measuring reading abilities: Concepts, source, and application. London: Hodder and Stoughton.

Rosalina, E., \& Nasrullah, N. (2020). The Correlation between self - esteem and student's reading comprehension. English Language Teaching Educational Journal, 2(2), 70-78. https://doi.org/10.12928/eltej.v2i2.1190

Snow, C. E.(2001). Reading for understanding: toward a research and development program in reading comprehension. Santa Monica: RAND Education Publisher.

Stanley, G., \& Tognolini, J. (2011). A standards perspective on the relationship between formative and summative assessment. New Directions: Assessment and Evaluation. A collection of papers. British Council. 